\title{
Ocular pulsations due to posttraumatic compromise of the orbital roof
}

田
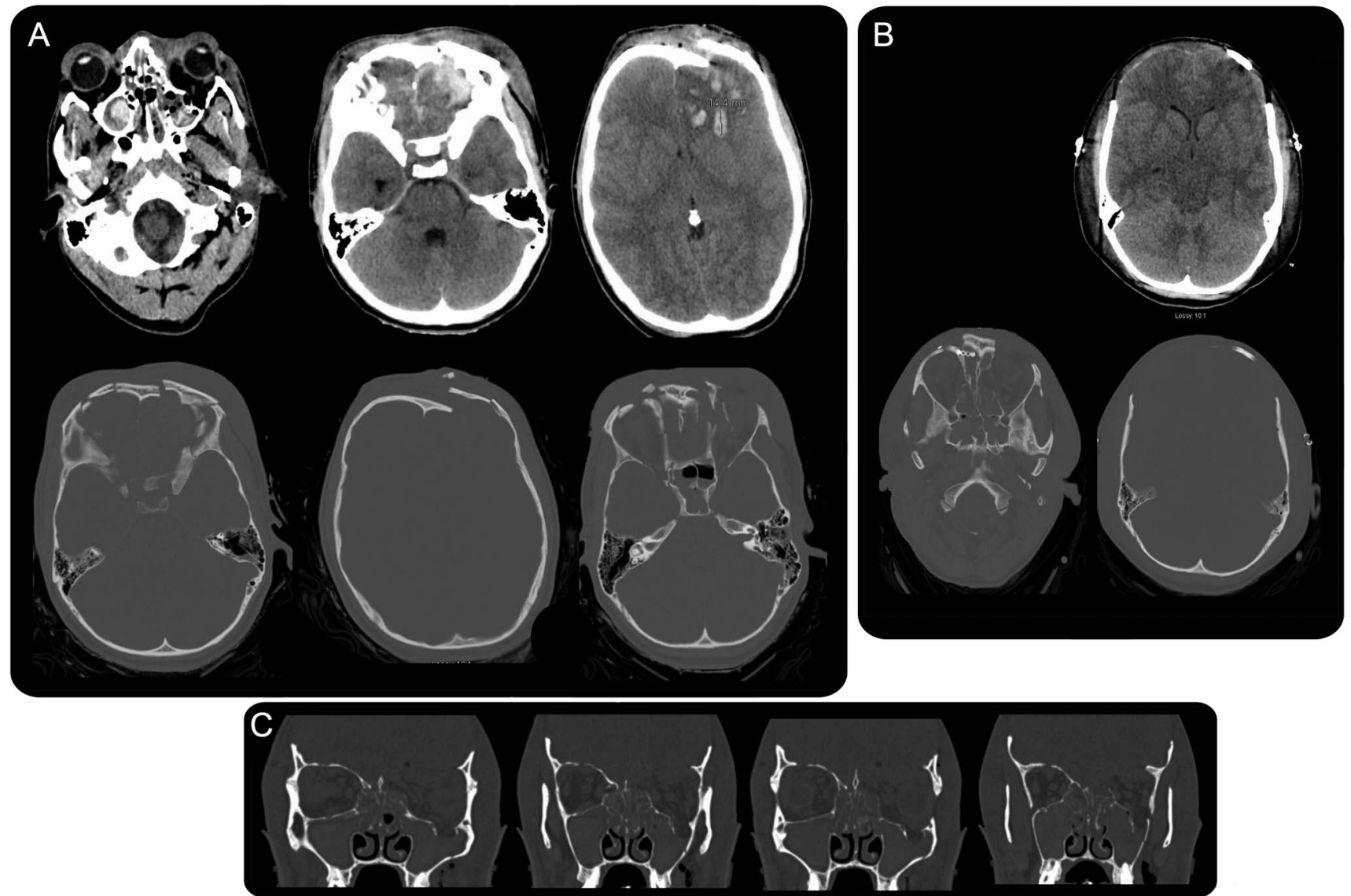

(A) Bifrontal hemorrhage with comminuted, complex fractures of the skull base, facial, and frontal bones. (B) After injury, the patient underwent a bifrontal craniectomy. Normally, titanium mesh is placed at an orbital roof fracture. Here, no mesh was used because no bone remained to anchor it (C).

Supplemental data at Neurology.org
A 21-year-old man was in a motor collision, resulting in skull fractures and subsequent craniectomy (figure). When he was able to communicate, 60 days after injury, he reported vertical oscillopsia and a throbbing sensation around his left eye. Examination revealed monocular left orbital pulsations (video on the Neurology ${ }^{\circledR}$ Web site at Neurology.org). Orbital pulsations can result from a cavernous carotid fistula, orbital venous varix, orbital arteriovenous malformation, orbital tumor, intraorbital ophthalmic artery aneurysm, tricuspid regurgitation, or orbital wall defects associated with neurofibromatosis. Orbital pulsations have been rarely reported due to incompetent orbital bone structure. This case illustrates orbital pulsations associated with postsurgical, posttraumatic oscillopsia.

John H. Pula, MD, Jorge C. Kattah, MD

From NorthShore University Health System (J.H.P.), Glenview, IL; and the University of Illinois College of Medicine in Peoria (J.C.K.). Study funding: No targeted funding reported.

Disclosures: The authors report no disclosures relevant to the manuscript. Go to Neurology.org for full disclosures.

Correspondence to Dr. Pula: JPula@NorthShore.org 


\section{Neurology}

\section{Ocular pulsations due to posttraumatic compromise of the orbital roof John H. Pula and Jorge C. Kattah \\ Neurology 2014;83;771 \\ DOI 10.1212/WNL.0000000000000706}

This information is current as of August 18, 2014

\section{Updated Information \& Services \\ Supplementary Material \\ Subspecialty Collections}

Permissions \& Licensing

Reprints including high resolution figures, can be found at: http://n.neurology.org/content/83/8/771.full

Supplementary material can be found at: http://n.neurology.org/content/suppl/2014/08/15/WNL.0000000000000 706.DC1

This article, along with others on similar topics, appears in the following collection(s):

Orbit

http://n.neurology.org/cgi/collection/orbit

Oscillopsia

http://n.neurology.org/cgi/collection/oscillopsia

Information about reproducing this article in parts (figures,tables) or in its entirety can be found online at:

http://www.neurology.org/about/about_the_journal\#permissions

Information about ordering reprints can be found online:

http://n.neurology.org/subscribers/advertise

Neurology ${ }^{\circledR}$ is the official journal of the American Academy of Neurology. Published continuously since 1951, it is now a weekly with 48 issues per year. Copyright @ 2014 American Academy of Neurology. All rights reserved. Print ISSN: 0028-3878. Online ISSN: 1526-632X.

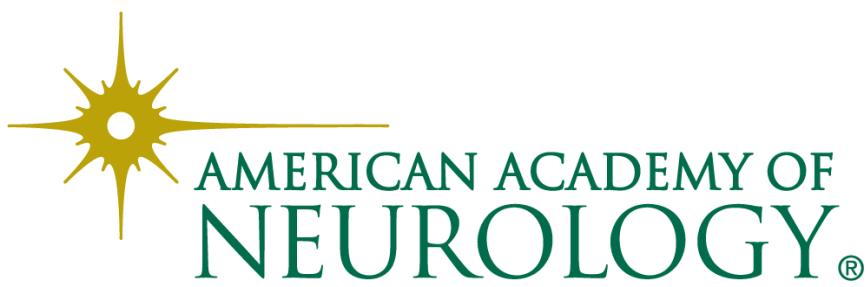

